\title{
Anthelmintic effect of Indigofera tinctoria L on Haemonchus contortus obtained from sheep in Indonesia
}

\author{
Iskandar Muda ${ }^{1,2}$ (D) Joko Prastowo ${ }^{3}$ (i), Wisnu Nurcahyo3 ${ }^{(i)}$ and Sarmin Sarmin ${ }^{4}$ (D) \\ 1. Doctoral Study Program of Veterinary Science, Faculty of Veterinary Medicine, Universitas Gadjah Mada, Bulaksumur \\ Sleman, Yogyakarta 55281, Indonesia; 2. Animal Husbandry Training Center - Batu, Jl. Songgoriti 24 Batu, East Java, \\ 65312, Indonesia; 3. Department of Parasitology, Faculty of Veterinary Medicine, Universitas Gadjah Mada, Bulaksumur \\ Sleman, Yogyakarta 55281, Indonesia; 4. Department of Physiology, Faculty of Veterinary Medicine, Universitas Gadjah \\ Mada, Bulaksumur Sleman, Yogyakarta 55281, Indonesia. \\ Corresponding author: Joko Prastowo, e-mail: joko2465@ugm.ac.id \\ Co-authors: IM: is_muda11@yahoo.com, WN: wisnu-nc@ugm.ac.id, SS: sarminkh76@ugm.ac.id \\ Received: 30-11-2020, Accepted: 08-04-2021, Published online: 22-05-2021
}

doi: www.doi.org/10.14202/vetworld.2021.1272-1278 How to cite this article: Muda I, Prastowo J, Nurcahyo W, Sarmin S (2021) Anthelmintic effect of Indigofera tinctoria L on Haemonchus contortus obtained from sheep in Indonesia, Veterinary World, 14(5): 1272-1278.

\begin{abstract}
Background and Aim: Hemonchosis has resulted in huge economic losses for sheep farmers worldwide. Secondary metabolite compounds from Indigofera tinctoria L. can be used as anthelmintics. This study aimed to evaluate the in vitro and in vivo effects of I. tinctoria L. aqueous extract (IAE) as an anthelmintic against adult Haemonchus contortus isolated from sheep.

Materials and Methods: Ten active adult worms were placed in each Petri dish containing $25 \mathrm{~mL}$ of IAE, each having a different concentration of IAE (at concentrations 100, 120, 140, 160, 180, 200, and $220 \mathrm{mg} / \mathrm{mL}$ ). Each experiment was repeated. The positive control used $1 \%$ albendazole, and the negative control used $0.62 \%$ saline water. The number of immobile worms and the time of mortality were recorded after 2, 4, 6, and $8 \mathrm{~h}$. The dead worms were subsequently tested using scanning electron microscopy (SEM) and sodium dodecyl sulfate-polyacrylamide gel electrophoresis. In the in vivo study, 15 sheep with an average fecal egg count (FEC) of 1000 eggs per gram were treated with IAE for 9 days: Group A (negative control, saline water 0.62\%), Group B $(21 \mathrm{mg} / \mathrm{mL})$, Group C (41 mg/mL), Group D (62 mg/mL), and Group E (positive control, albendazole $100 \mathrm{mg} / \mathrm{mL}$ ). Measurements of the body weight, FEC reduction test, and hematology testing were performed on days 0,7 , and 14. SEM was performed using worms found from the abomasum of slaughtered sheep.

Results: The leaves of I. tinctoria L. contained a number of secondary metabolites, including total tannins, saponins, flavonoids, and alkaloids. The most effective concentration that killed the adult $H$. contortus worms was $220 \mathrm{mg} / \mathrm{mL}$ (93.33\% mortality) after $8 \mathrm{~h}$ of treatment. The electrophoresis results showed that the protein band at a dose of $22 \%$ was less than that of the control. The highest FECR value of the treatment group on the $14^{\text {th }}$ day after treatment was at a dose of $62 \mathrm{mg} / \mathrm{mL}$. The highest weight gain as well as the highest increased hemoglobin $(\mathrm{Hb})$, packed cell volume (PCV), and total erythrocyte count (TEC) values on the $14^{\text {th }}$ day after treatment were at a dose of $41 \mathrm{mg} / \mathrm{mL}$. The SEM results showed that IAE treatment caused the worms' anterior parts to become wrinkled with thick creases and cuticle abrasion (in vitro) and the anterior part to shrink along with the presence of aggregates in the worm cuticle (in vivo).
\end{abstract}

Conclusion: The aqueous extract of I. tinctoria contains tannins, saponins, flavonoids, and alkaloids and has an anthelmintic effect with decreased FEC, increased weight gain, $\mathrm{Hb}, \mathrm{PCV}$, and TEC, causing damage to the worms' body and reducing the protein profile of adult $H$. contortus worms.

Keywords: anthelmintic, Haemonchus contortus, Indigofera tinctoria, scanning electron microscopy, sheep.

\section{Introduction}

Haemonchus contortus is a blood-sucking gastrointestinal worm from the nematode class (Familia: Trichostrongylidae). In the sheep husbandry business, hemonchosis has caused huge economic losses. $H$. contortus infestation disrupts the health of farmed sheep in Indonesia. In sheep, hemonchosis can cause mortality, decreased production, stunted growth, and low body weight [1].

Copyright: Muda, et al. Open Access. This article is distributed under the terms of the Creative Commons Attribution 4.0 International License (http://creativecommons.org/licenses/by/4.0/), which permits unrestricted use, distribution, and reproduction in any medium, provided you give appropriate credit to the original author(s) and the source, provide a link to the Creative Commons license, and indicate if changes were made. The Creative Commons Public Domain Dedication waiver (http://creativecommons.org/ publicdomain/zero/1.0/) applies to the data made available in this article, unless otherwise stated.
The prevalence of hemonchosis in sheep is still quite high. Baihaqi et al. [2] stated that the prevalence of Haemonchus sp. in thin-tailed sheep in Wonosobo, Indonesia, was $55.41 \%$. Abdo et al. [3] stated that the hemonchosis infection rate in sheep slaughtered at a slaughterhouse in Bishoftu, Ethiopia was $69.6 \%$, with a prevalence in young and adult cattle of $66.9 \%$ and 59\%, respectively. Bibi et al. [4] reported that the prevalence of hemonchosis in sheep in Pakistan was $55 \%$. Secondary metabolite compounds from plant extracts can be used as anthelmintics. Indigofera tinctoria L. is very commonly grown and can be easily found in Indonesia. Kusumawati et al. [5] stated that I. tinctoria contains tannins. Renukadevi and Sultana [6] added that the leaf extract of I. tinctoria contains flavonoids, saponins, sterols, terpenoids, phenolic acids, quinones, and tannins. Some plants 
that are the sources of tannins have an anthelmintic effect on nematodes [7]. Maestrini et al. [8] added that saponins also have an anthelmintic effect. Tannin and flavonoids have effective anthelmintic effects against worm eggs and larvae [9].

This study aimed to evaluate the in vitro and in vivo effects of I. tinctoria L. aqueous extract as an anthelmintic against adult $H$. contortus isolated from sheep.

\section{Materials and Methods \\ Ethical approval}

This study was approved by the Institutional Ethical Committee, Faculty of Veterinary Medicine, Universitas Gadjah Mada, Yogyakarta, Indonesia (No. 0016/EC-FKH/Int/2019).

\section{Study period and location}

The study was conducted from April 2019 to October 2020. All samples were processed in the Parasitology Laboratory of Veterinary Faculty of Gadjah Mada University, except for scanning electron microscopy (SEM) samples that were processed in the Laboratory of Indonesian Institute of Sciences.

\section{Plant collection and extraction}

The leaves of I. tinctoria L. were obtained from Maguwoharjo Village, Depok District, Sleman Regency, Yogyakarta (7.46'43" "S, 110.23'21"' E, and 140 MASL). The plant specimens were identified at the Plant Taxonomy Laboratory of the Biology Faculty, Universitas Gadjah Mada, Yogyakarta, Indonesia. A number of I. tinctoria L. leaves were cleaned, dried in a drying room, and stored until they were used for the extraction process. Each of the dry I. tinctoria leaves $(10,12,14,16,18,20$, and $22 \mathrm{~g})$ was placed in $100 \mathrm{~mL}$ of distilled water and then incubated at $90^{\circ} \mathrm{C}$ for $15 \mathrm{~min}$. The solution was filtered using filter paper, and the filtrate $(100,120,140,160,180,200$, and $220 \mathrm{mg} / \mathrm{mL}$ ) was stored in the refrigerator until SEM and sodium dodecyl sulfate-polyacrylamide gel electrophoresis (SDS-PAGE) were conducted [10].

\section{Determinination of qualitative plant phytochemical}

The content of secondary metabolites in I. tinctoria leaves was determined using the spectrophotometric method. The total equivalent tannic acid was determined as described previously [11,12]. Total flavonoids were determined using the spectrophotometric method [13]. The results of the total equivalent tannic acid, saponins, flavonoids, and alkaloid equivalent quinine were expressed as $\% \mathrm{w} / \mathrm{w}$ (weight of tannins or flavonoids or saponin or alkaloid per weight of sample $\times 100$ ).

\section{In vitro study}

The $H$. contortus worms were obtained directly from the abomasum of naturally infected sheep slaughtered at a slaughterhouse in Sleman, Yogyakarta, Indonesia. This abomasum was taken to the Parasitology Laboratory of the Faculty of Veterinary Medicine, Universitas Gadjah Mada, Yogyakarta. The worm collection was done by opening the abomasum and cutting the curvature. Subsequently, the abomasum contents were poured out carefully, and the visible worms were collected and put into a container containing $0.62 \%$ physiological $\mathrm{NaCl}$ solution [10].

The I. tinctoria L. aqueous extract (IAE) was prepared 1 day before the worm mortality test according to the treatment dose. Ten active adult worms were placed in a Petri dish containing $25 \mathrm{~mL}$ of IAE. This experiment with each treatment group (negative control, 100, 120, 140, 160, 180, 200, and $220 \mathrm{mg} /$ mL IAE, and positive control) was repeated. The positive control was administered albendazole $1 \%$, and the negative control was administered $0.62 \%$ physiological $\mathrm{NaCl}$. Observations were made after 2, 4, 6 , and $8 \mathrm{~h}$. The time of mortality and the number of immobile worms were recorded. Worm mortality was characterized by worms that did not move when the Petri dish was shaken or touched with a needle. The dead worms were put in an absolute ethanol solution and stored at $4{ }^{\circ} \mathrm{C}$ until they were used for SEM and SDS-PAGE [10].

\section{In vivo study}

Fifteen sheep with an average fecal egg count (FEC) of 1000 egg per gram (EPG) that was infected with L3 $H$. contortus were treated with IAE for 9 days: Negative control (saline water $0.62 \%$ ), Group B (21 mg/mL), Group C (41 mg/mL), Group D (62 mg/ $\mathrm{mL}$ ), and positive control (albendazole $100 \mathrm{mg} / \mathrm{mL}$ ). The variables analyzed included body weight, EPG, hematology results, and SEM. Observations, data collection, and testing were carried out on days 0,7 , and 14 [14]. SEM was performed using worms found in the abomasum of slaughtered sheep.

\section{SEM}

Adult worms that had died from the anthelmintic test (in vitro) and adult worms found in the abomasum (in vivo) were used in this test. The worm samples were fixed in absolute ethanol. Subsequently, the following were carried out: Solid specimen preparation by cleaning in a cacodylate buffer for $2 \mathrm{~h}$, prefixation in $2.5 \%$ glutaraldehyde for $48 \mathrm{~h}$, fixation in $2 \%$ tannic acid with four washes in cacodylate buffer and distilled water, dehydrated in graded alcohol, and dried in tertiary butanol. Dry samples were coated with copper for 15 min and observed with SEM (JEOL JSM5319LV, JEOL USA, Inc.) [15].

\section{SDS-PAGE}

This test used adult worms that died from the anthelmintic test. The specimens were washed several times using phosphate-buffered saline (PBS) to remove debris and host-derived materials. The specimens were crushed in $100 \mathrm{uL}$ of PBS. The dissolved protein was isolated through $1200 \times$ centrifugation for $5 \mathrm{~min}$ and used for electrophoresis. Electrophoresis was carried out based on the method used by Sambodo et al. [10]. Dissolved protein samples and markers (Thermo Scientific, Lithuania) were boiled for $2 \mathrm{~min}$ 
in a sample buffer with a volume ratio of $4: 1$ containing $50 \%$ glycerol, $10 \%$ SDS, $2.5 \%$ DTT, and $0.05 \%$ $(\mathrm{w} / \mathrm{v})$ bromophenol blue liquid as a marker dye. Electrophoresis was carried out at $100 \mathrm{~V}$ in a vertical slab gel system. After electrophoresis, the gel was stained with $0.2 \%(\mathrm{w} / \mathrm{v})$ Coomassie blue.

\section{Fecal egg-count reduction test (FECRT)}

Fecal sample collection was performed directly from the rectum. The EPG calculation was carried out using the McMaster egg counting technique (flotation procedures). The percentage decrease in the number of worm EPG of feces or FECR was calculated according to the following:

$$
\begin{gathered}
\text { EPG pre-treatment }- \\
\text { FECR }(\%)=\frac{\text { EPG post-treatment }}{\text { EPG pre-treatment }} \times 100
\end{gathered}
$$

\section{Hematology}

Blood was collected from all sheep through the jugular vein $(2 \mathrm{~mL} / \mathrm{sheep})$. The parameters analyzed included hemoglobin $(\mathrm{Hb})$, packed cell volume (PCV), and total erythrocyte count (TEC) [14].

\section{Statistical analysis}

Adult worm mortality, body weight, EPG, and hematology data were analyzed using a one-way analysis of variance (ANOVA). The SEM and SDS-PAGE results were analyzed descriptively.

\section{Results}

\section{Determining qualitative plant phytochemical}

The quantitative phytochemical analysis showed that the leaves of I. tinctoria L. contained a number of secondary metabolites such as total tannins, saponins, flavonoids, and alkaloids (Table-1). The largest secondary metabolite compound was total tannins $(5.43 \% \mathrm{w} / \mathrm{w})$ and flavonoids $(3.45 \% \mathrm{w} / \mathrm{w})$.

Table-1: Quantitative phytochemical analysis.

\begin{tabular}{lc}
\hline Secondary metabolite compounds & \%w/w \\
\hline Total Tannins & 5.43 \\
Total Saponins & 1.22 \\
Total Flavonoids & 3.45 \\
Total Alkaloids & 0.11 \\
\hline
\end{tabular}

\section{In vitro study}

Table-2 shows that IAE had a statistically significant effect on the mortality rate of $H$. contortus after 8 $\mathrm{h}$ of treatment $(\mathrm{p}<0.05)$. H. contortus deaths occurred after $8 \mathrm{~h}$ of immersion at a dose of $120 \mathrm{mg} / \mathrm{mL}$ and after $6 \mathrm{~h}$ at a dose of $160 \mathrm{mg} / \mathrm{mL}$. In the negative control group, there was no worm mortality within $8 \mathrm{~h}$ of immersion. The most effective concentration that terminated adult $H$. contortus worms was obtained at a $220 \mathrm{mg} / \mathrm{mL}$ concentration, which resulted in $93.33 \%$ mortality (Table-2).

Figures- 1 and 2 show the significant ultrastructural changes in adult $H$. contortus worms after in vitro immersion in IAE. In the control worms, their anterior part did not shrink, their cuticle had no aggregate, and there was no damage to the cuticle surface. However, damage occurred in the treatment worms (Figures-1, $2 \mathrm{~b}$, and $1,2 \mathrm{c}$ ). Their anterior end was wrinkled with thick folds, and their cuticles were abraded.

Figure-3 shows that the electrophoresis of the soluble protein of $H$. contortus after treatment produced five protein bands with molecular weights of 10.8, 15.8, 35.4, and $51.7 \mathrm{kDa}$ in $22 \%$ IAE. Conversely, at a dose of $10 \%$, there were six protein bands. There were eight protein bands with molecular weights of 10.8, 15.8, 35.4, 40.8, $47.0,51.7,56.9$, and $72.1 \mathrm{kDa}$ in the control group.

\section{In vivo study}

Table-3 shows the highest FECRT value in the treatment group on the $14^{\text {th }}$ day after treatment at a dose of $62 \mathrm{mg} / \mathrm{mL}$. The results of the ANOVA showed significant differences $(p<0.05)$. Table-4 shows that the highest weight gain on the $14^{\text {th }}$ day after treatment at a dose of $41 \mathrm{mg} / \mathrm{mL}$, which is $0.57 \mathrm{~kg}$ or $2.55 \%$, and in the negative control, a weight loss of $0.40 \mathrm{~kg}$ or $2.08 \%$. The highest increased $\mathrm{Hb}, \mathrm{PCV}$, and TEC values at day 14 were at a dose of $41 \mathrm{mg} / \mathrm{mL}$, although the ANOVA did not show a significant difference $(p<0.05$; Table-5). The SEM results showed that IAE in vivo treatment caused the anterior part to shrink and aggregate to appear in the worm cuticle (Figure-4).

\section{Discussion}

The quantitative phytochemical analysis showed that I. tinctoria L. contained secondary metabolites

Table-2: Effect of IAE concentrations on the mortality rate of Haemonchus contortus after $8 \mathrm{~h}$ of immersion.

\begin{tabular}{lcccc}
\hline Treatment & \multicolumn{4}{c}{ Time of death $(\mathbf{h})$} \\
\cline { 2 - 5 } & $\mathbf{2}$ & $\mathbf{4}$ & $\mathbf{6}$ & $\mathbf{8}$ \\
\hline $\mathrm{NaCl} 0.62 \%$ & $0.00+0.00$ & $0.00+0.00$ & $0.00+0.00^{\mathrm{a}}$ & $0.00+0.00^{\mathrm{a}}$ \\
$\mathrm{IAE} 100 \mathrm{mg} / \mathrm{mL}$ & $0.00+0.00$ & $0.00+0.00$ & $0.00+0.00^{\mathrm{a}}$ & $0.00+0.00^{\mathrm{a}}$ \\
IAE $120 \mathrm{mg} / \mathrm{mL}$ & $0.00+0.00$ & $0.00+0.00$ & $0.00+0.00^{\mathrm{a}}$ & $13.33+11.54^{\mathrm{b}}$ \\
IAE $140 \mathrm{mg} / \mathrm{mL}$ & $0.00+0.00$ & $0.00+0.00$ & $0.00+0.00^{\mathrm{a}}$ & $16.67+5.77^{\mathrm{b}}$ \\
IAE $160 \mathrm{mg} / \mathrm{mL}$ & $0.00+0.00$ & $0.00+0.00$ & $10.00+17.32^{\mathrm{b}}$ & $36.66+5.77^{\mathrm{c}}$ \\
IAE $180 \mathrm{mg} / \mathrm{mL}$ & $0.00+0.00$ & $0.00+0.00$ & $16.66+20.81^{\mathrm{b}}$ & $56.66+15.27^{\mathrm{d}}$ \\
IAE $200 \mathrm{mg} / \mathrm{mL}$ & $0.00+0.00$ & $0.00+0.00$ & $33.33+28.8^{\mathrm{c}}$ & $76.66+5.77^{\mathrm{e}}$ \\
IAE $220 \mathrm{mg} / \mathrm{mL}$ & $0.00+0.00$ & $0.00+0.00$ & $56.66+15.27^{\mathrm{c}}$ & $93.33+11.54^{\mathrm{f}}$ \\
Albendazole $1 \mathrm{mg} / \mathrm{mL}$ & $3.33+5.77$ & $96.66+5.77$ & $100.00+0.00^{\mathrm{d}}$ & $100.00+0.00^{\mathrm{f}}$ \\
\hline $\mathrm{a}, \mathrm{b}, \mathrm{c}, \mathrm{d}, \mathrm{e}, \mathrm{f}$ Different superscripts within the same column indicates significant differences $(\mathrm{p}<0.05)$. IAE $=$ Indigofera tinctoria & & &
\end{tabular}




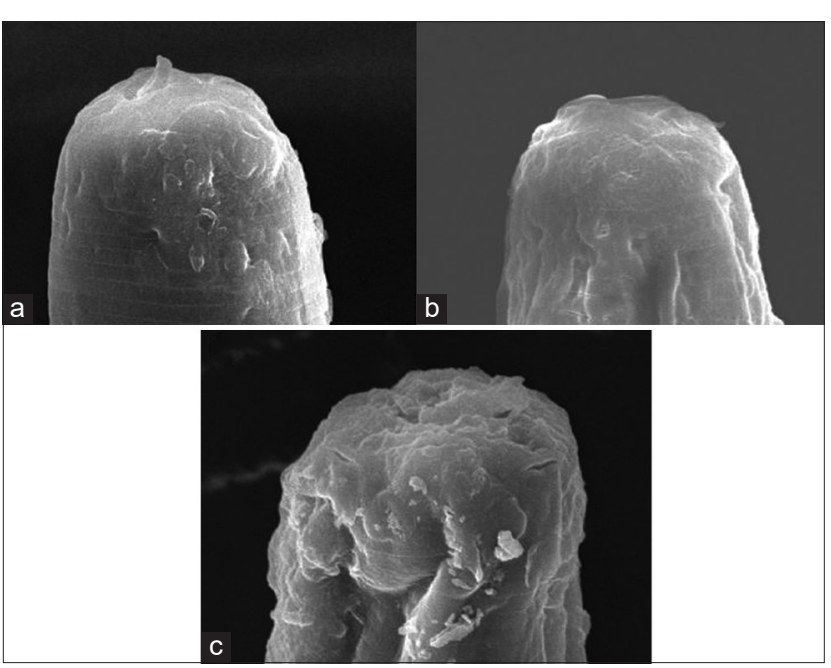

Figure-1: Ultrastructure of the anterior part of the worm: (a) Negative control. (b) A dose of $100 \mathrm{mg} / \mathrm{mL}$ : Anterior end was constricted. (c) A dose $220 \mathrm{mg} / \mathrm{mL}$ : Anterior end was constricted with thick folds.

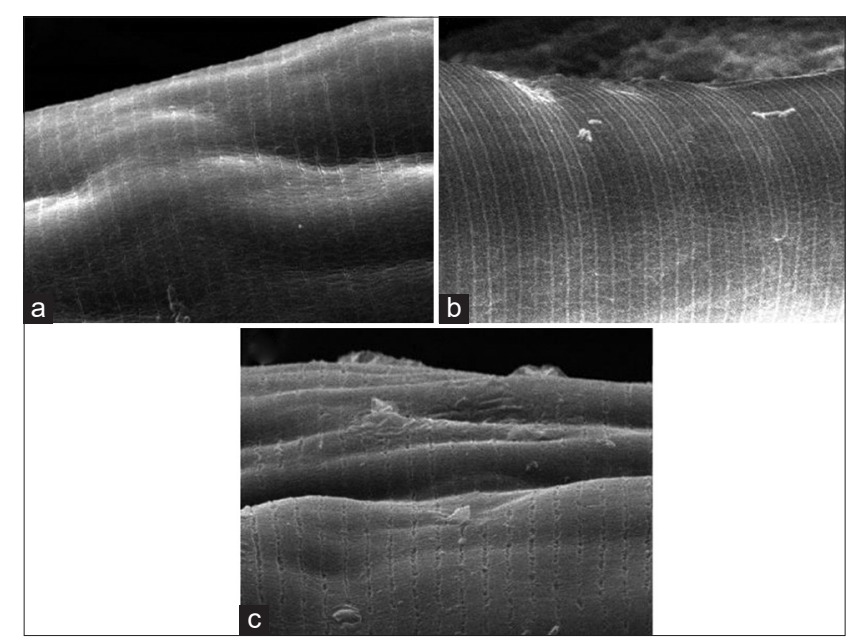

Figure-2: Ultrastructure of the midsection cuticle of the worm's body: (a) Negative control. (b) A dose of $100 \mathrm{mg}$ $\mathrm{mL}$ : Cuticle surface abraded. (c) A dose $220 \mathrm{mg} / \mathrm{mL}$ : The cuticle surface was wavy and abraded.

with the highest amount of total tannins and flavonoids. The previous studies conducted by Rahman et al. [16] and Verma and Suresh [17] found that I. tinctoria leaves contain flavonoids and alkaloids. Mishra et al. [18] also found that tannins and saponins are present in I. tinctoria. Tannins, saponins, flavonoids, and alkaloids in the extract of $P$. falcaria have previously been shown to have an anthelmintic effect against $H$. contortus [19]. Klongsiriwet et al. [20] added that the combination of flavonoids and tannins had a synergistic anthelmintic effect against $H$. contortus. Joshua et al. [11] stated that the medicinal potential of plant leaf extracts could be identified from their phytochemical components.

In the current study, the highest mortality in $H$. contortus occurred after $8 \mathrm{~h}$ of immersion, which was believed to be caused by the reaction of the collective presence of bioactive compounds in the plant extracts. This study's findings are similar to those of

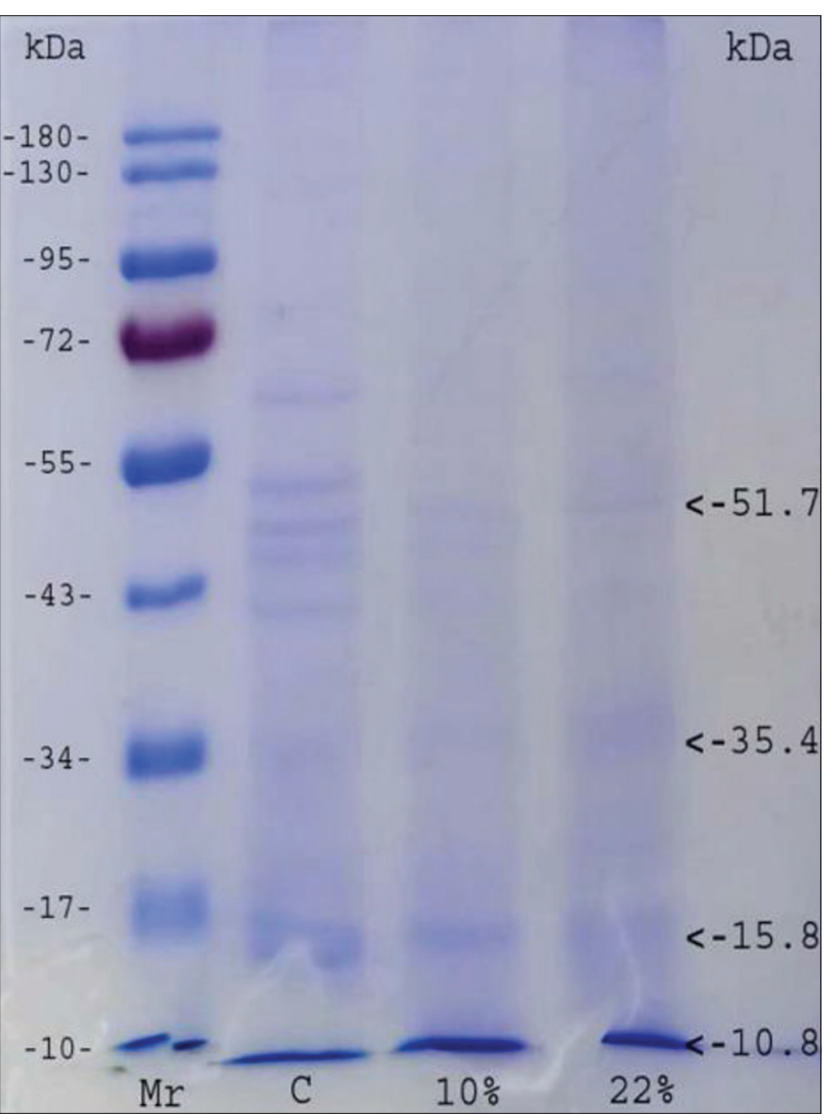

Figure-3: Sodium dodecyl sulfate-polyacrylamide gel electrophoresis electropherogram of Haemonchus contortus. Line 1 protein marker $(\mathrm{Mr})$, line 2 worm protein of negative control (C), line 3, and 4 worm protein after immersion in $10 \%$ and $22 \%$ Indigofera tinctoria L. aqueous extract.

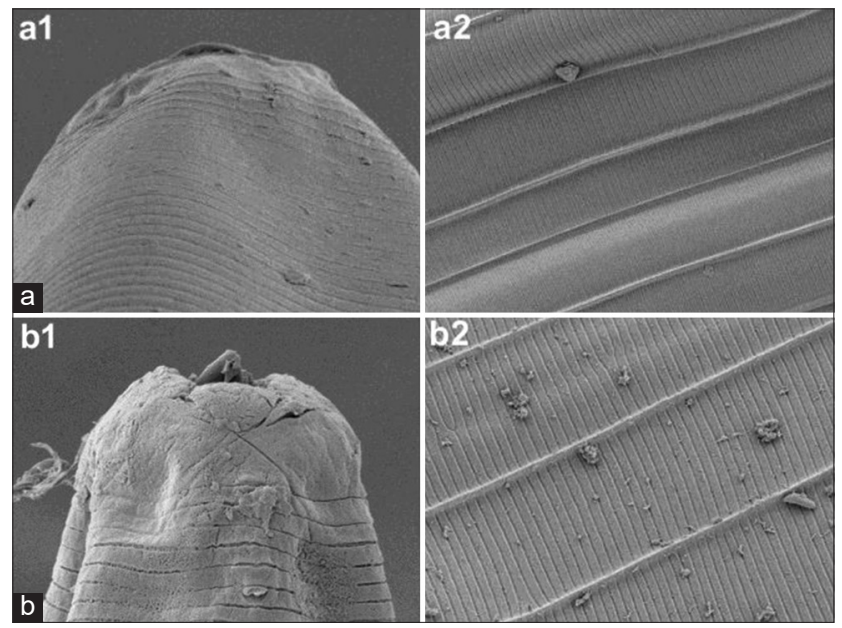

Figure-4: Ultrastructure of the anterior and the midsection part of the worm: (a) Negative control. (b) a dose $21 \mathrm{mg} / \mathrm{mL}$.

Ferreira et al. [21], who reported that the leaf extract of Annona muricata L. could completely inhibit the motility of adult $H$. contortus worms in the first 6-8 h. Ahmed et al. [22] stated that Artemisia herba-alba and Punica granatum had a significant effect on the mortality rate of adult $H$. contortus after $7 \mathrm{~h}$ of exposure. Zaman et al. [23] reported that herbal complex extracts could cause $100 \%$ death in adult $H$. contortus worms $8 \mathrm{~h}$ post-exposure. Widiarso et al. [24] 
Table-3: The effect of IAE on fecal egg counts.

\begin{tabular}{lccc}
\hline Dose of IAE $(\mathbf{m g} / \mathbf{m L})$ & Eggs per gram & $\begin{array}{c}\text { Fecal egg-count } \\
\text { reduction test (\%) }\end{array}$ \\
\cline { 2 - 4 } & Pre-treatment & Post-treatment day 7 & Post-treatment day 14 \\
\hline Saline water 0.62\% & $1250.00 \pm 317.54^{\mathrm{a}}$ & $666.67 \pm 44.10^{\mathrm{a}}$ & $383.33 \pm 83.33^{\mathrm{a}}$ \\
21 & $800.00 \pm 200.00^{\mathrm{a}}$ & $416.67 \pm 116.67^{\mathrm{a}}$ & $50.00 \pm 50.00^{\mathrm{b}}$ \\
41 & $850.00 \pm 202.07^{\mathrm{a}}$ & $583.33 \pm 216.67^{\mathrm{a}}$ & $50.00 \pm 28.87^{\mathrm{a}}$ \\
62 & $750.00 \pm 325.32^{\mathrm{a}}$ & $350.00 \pm 76.38^{\mathrm{a}}$ & 93.75 \\
Albendazole & $1383.33 \pm 231.54^{\mathrm{a}}$ & $0.00 \pm 0.00 \mathrm{~b}$ & 94.12 \\
\hline
\end{tabular}

$\mathrm{a}, \mathrm{b}, \mathrm{c}, \mathrm{d}$ Different superscripts indicate significant differences $(\mathrm{p}<0.05)$. IAE $=$ Indigofera tinctoria crude aqueous extract

Table-4: The effect of IAE on sheep body weight $(\mathrm{kg})$.

\begin{tabular}{lccc}
\hline $\begin{array}{l}\text { Dose of IAE } \\
\text { ( } \mathbf{m g} / \mathbf{m L})\end{array}$ & $\begin{array}{c}\text { Pre- } \\
\text { treatment }\end{array}$ & $\begin{array}{c}\text { Post- } \\
\text { treatment } \\
\text { day 79 }\end{array}$ & $\begin{array}{c}\text { Post- } \\
\text { treatment } \\
\text { day 14 }\end{array}$ \\
\hline Saline water & $19.25 \pm 0.70^{\mathrm{a}}$ & $20.10 \pm 0.89^{\mathrm{a}}$ & $18.85 \pm 0.60^{\mathrm{a}}$ \\
$0.62 \%$ & & & \\
21 & $22.10 \pm 0.40^{\mathrm{a}}$ & $22.42 \pm 0.52^{\mathrm{a}}$ & $21.88 \pm 0.06^{\mathrm{b}}$ \\
41 & $22.33 \pm 0.68^{\mathrm{a}}$ & $23.20 \pm 0.73^{\mathrm{a}}$ & $22.90 \pm 0.89^{\mathrm{b}}$ \\
62 & $20.43 \pm 0.96^{\mathrm{a}}$ & $20.80 \pm 1.00^{\mathrm{a}}$ & $20.67 \pm 0.71^{\mathrm{b}}$ \\
Albendazole & $21.55 \pm 1.68^{\mathrm{a}}$ & $22.08 \pm 1.86^{\mathrm{a}}$ & $22.08 \pm 1.52^{\mathrm{b}}$ \\
\hline
\end{tabular}

$\mathrm{a}, \mathrm{b}$ Different superscripts indicate significant differences

$(\mathrm{p}<0.05) . \mathrm{IAE}=$ Indigofera tinctoria crude aqueous extract

stated that the infusion of Gigantochloa apus could cause $100 \%$ mortality against $H$. contortus after $4 \mathrm{~h}$ of immersion. $H$. contortus adult worms' mortality is an effect of the tannins in the plant extract. Tannins can directly affect adult $H$. contortus worms by impairing the protective function and absorption of $H$. contortus [25]. Maestrini et al. [8] added that saponins could cause death by increasing the cell membrane permeability. Alkaloids work by affecting the activity of the worm muscles [26].

The damage to the anterior end and cuticle that experienced abrasion proved that IAE interacted with the nematode cuticle. Baihaqi et al. [19] stated that an in vitro extract of $P$. falcataria's bark waste caused damage to the buccal area, and aggregate built up in the cuticle annular. Acevado-Ramírez et al. [27] stated that Castanea sativa caused damage around the mouth, anus, vulva, copular bursa, and cuticle of worms. Martínez-ortíz-de-montellano et al. [28] added that the leaf extracts of Onobrychis viciifolia and Lysiloma latisiliquum caused changes in the transferal fold and thickening of the cuticle of adult H. contortus worms. Yoshihara et al. [29] added that Acacia mearnsii extract caused ruptures of the cuticle and transverse wrinkles on the body surface of adult H. contortus. Barone et al. [30] added that Cranberry vine extract caused aggregate accumulation in the cuticle and buccal areas of $H$. contortus. The peeling and wrinkling of adult $H$. contortus cuticle after soaking with Biophytum petersianum were reported by Sambodo et al. [10]. Tresia et al. [31] stated that cuticle damage and changes in the permeability of the worm cuticle were related to the active ingredients found in plants. Damage to the cuticle disrupts the protective function and absorption of nutrients, resulting in malnutrition and impaired motility, which causes the worms to die. The mechanism of cuticle damage occurs through the insertion of tannins into the lipid layer in the cuticle (glycosylation) and interaction with the proline and hydroxyproline collagen layers in the cuticle, resulting in changes in the cells [32].

Soaking $H$. contortus in I. tinctoria extract showed a decrease in the number of protein bands. Several studies have shown different numbers of protein bands. Sambodo et al. [10] stated that $H$. contortus soaked in a $10 \%$ dose of $B$. petersianum showed five protein bands with sizes of 9.3, 17.1, 50, 63.2, and $72.7 \mathrm{kDa}$. Mubarokah et al. [15] stated that A. catechu extract decreased the number of protein bands. Jaiswal et al. [33] added that in $H$. contortus females, there were 35 protein bands. In this study, the decrease in the number of protein bands was caused by secondary metabolites that disrupted the protein binding in the worms. Hoste et al. [34] stated that tannins could bind proline and hydroxyproline, while worm bodies are known to contain lots of proline and hydroxyproline. Zong et al. [25] added that tannins binding to proteins affected the physiological processes of worms and/ or modified the host immune response in eliminating adult worms.

The decreased EPG value after treatment was the same as the results of research conducted by Simon et al. [35], who stated that Combretum molle extract decreased the FEC in sheep infected with $H$. contortus. González-Cortazar et al. [36] stated that the aqueous extract of $L$. acapulcensis leaves reduced the EPG value of gastrointestinal nematodes in sheep. Sambodo et al. [14] also stated that the aqueous extract of Biophytum petersianum decreased the EPG value of $H$. contortus in goats. The decrease in the EPG value is believed to be caused by secondary compounds in I. tinctoria. The presence of flavonoids, tannins, saponins, and alkaloids in C. molle may be responsible for the anthelmintic effect of these plants [35]. GonzálezCortazar et al. [36] added that myricitrin (a flavonoid) is the main component for reducing the EPG value.

The treatment group's increased body weight is believed to be due to the loss of most of the worms in the abomasum of the treated animals so that the absorption of nutrients from the feed was improved. These results are consistent with those of Sambodo et al. [14], who stated that B. petersianum extract increased the body weight of goats infected with $H$. contortus. Eguale et al. [37] stated that this could 
Table-5: The effect of IAE on sheep hematology.

\begin{tabular}{lcccc}
\hline Blood parameters & Dose of IAE $(\mathbf{m g} / \mathbf{m L})$ & Pre-treatment & Post-treatment day 7 & Post-treatment day 14 \\
\hline $\mathrm{Hb}(\mathrm{g} / \mathrm{dl})$ & Saline water $0.62 \%$ & $12.56 \pm 0.73$ & $12.40 \pm 0.30$ & $12.47 \pm 0.64$ \\
& 21 & $11.23 \pm 0.98$ & $10.73 \pm 0.54$ & $11.33 \pm 0.95$ \\
& 41 & $9.83 \pm 0.82$ & $11.23 \pm 0.39$ & $12.43 \pm 0.34$ \\
& 62 & $10.70 \pm 0.69$ & $10.73 \pm 0.70$ & $11.13 \pm 0.75$ \\
$\mathrm{PCV}(\%)$ & Albendazole & $10.30 \pm 0.35$ & $9.90 \pm 0.0 .11$ & $11.00 \pm 0.30$ \\
& Saline water 0.62\% & $35.10 \pm 1.95$ & $36.50 \pm 1.31$ & $35.47 \pm 1.74$ \\
& 21 & $32.63 \pm 3.28$ & $31.20 \pm 1.70$ & $35.97 \pm 1.81$ \\
$\mathrm{TEC}$ (million/UI) & 41 & $29.67 \pm 1.51$ & $33.57 \pm 0.99$ & $32.23 \pm 1.98$ \\
& 62 & $32.73 \pm 2.44$ & $32.50 \pm 2.51$ & $32.47 \pm 1.46$ \\
& Albendazole & $31.57 \pm 1.14$ & $29.93 \pm 1.23$ & $13.24 \pm 0.88$ \\
& Saline water 0.62\% & $12.92 \pm 0.84$ & $13.45 \pm 0.50$ & $12.32 \pm 0.59$ \\
& 21 & $12.12 \pm 0.67$ & $11.83 \pm 0.63$ & $12.15 \pm 0.89$ \\
& 41 & $10.04 \pm 1.97$ & $11.34 \pm 1.41$ & $11.00 \pm 0.92$ \\
\hline
\end{tabular}

Overall values do not differ significantly $(\mathrm{p}<0.05) ; \mathrm{Hb}=$ Hemoglobin, $\mathrm{PCV}=$ Packed cell volume, TEC=Total erythrocyte count, $\mathrm{SE}=$ Standard error

occur in livestock due to reduced blood plasma and protein associated with the presence of parasites.

The blood test results in this study were similar to those of Meenakshisundaram et al. [38], who stated that the ethanol extract treatment of I. tinctoria increased the $\mathrm{Hb}, \mathrm{PCV}$, and TEC values in sheep infected with gastrointestinal parasites. Eguale et al. [37] stated that Coriandrum sativum extract increased the PCV value 7 days after treatment. The increased hematological values are believed to be due to the loss of worm parasites in the abomasum so that the blood components can be better absorbed by the body. The increased $\mathrm{Hb}$ is probably due to increased iron absorption [38].

The SEM results at an in vivo stage are consistent with the SEM results at the in vitro stage. Changes in the ultrastructure of helminth parasites prove a strong interaction with IAE. This study's results are similar to those of Martínez-ortíz-de-montellano et al. [28], which found that Tzalam leaf extract causes aggregates in the anterior end of $H$. contortus.

\section{Conclusion}

IAE contains tannins, saponins, flavonoids, and alkaloids. Aqueous extract of I. tinctoria L. has an anthelmintic effect, resulting in decreased FEC, increased weight gain, $\mathrm{Hb}, \mathrm{PCV}$, and TEC, causing damage to the worms' body and reducing the protein profile of adult $H$. contortus worms.

\section{Authors' Contributions}

JP and IM: Designed and managed the study. IM: Collected and analyzed the samples. IM and SS: Wrote the manuscript. JK and WN: Reviewed the manuscript. All authors have read and approved the final manuscript.

\section{Acknowledgments}

The authors are grateful to the Office of Agriculture Human Resources Development and Agriculture Extension, The Ministry of Agriculture of the Republic of Indonesia for the financial support through a Domestic Graduate Scholarship (Grant no. 529/KPTS/Kp.320/8/2017).

\section{Competing Interests}

The authors declare that they have no competing interests.

\section{Publisher's Note}

Veterinary World remains neutral with regard to jurisdictional claims in published institutional affiliation.

\section{References}

1. Mengist, Z., Abebe, N., Gugsa, G. and Kumar, N. (2014) Assessment of small ruminant Haemonchosis and its associated risk factors in and around Finoteselam, Ethiopia. IOSR J. Agric. Vet. Sci., 7(12): 36-41.

2. Baihaqi, Z.A., Widiyono, I. and Nurcahyo, W. (2019) Prevalence of gastrointestinal worms in Wonosobo and thin-tailed sheep on the slope of Mount Sumbing, Central Java, Indonesia. Vet. World, 12(11): 1866-1871.

3. Abdo, B., Nur, A., Abera, B., Lemma, D. and Eticha, E. (2017) Prevalence and associated risk factors of Haemonchosis among small ruminants slaughtered in Bishoftu Elfora Export Abbatoir, Ethiopia. Acta Parasitol. Glob., 8(2): 73-78.

4. Bibi, R., Afshan, K., Khan, I.A., Iqbal, Z., Kayani, A.R., Mushtaq, M., Irfan, M., Qayyun, M. and Hasan, M.F. (2017) Phenotyping and prevalence of Haemonchus contortus (Nematode: Trichostrongylidae) in ruminants from endemic areas of Pakistan: Influence of host species and geographical area on phenotypic traits of worms. Pak. Vet. $J ., 37(2): 170-174$.

5. Kusumawati, F., Riyadi, P.H. and Rianingsih, L. (2016) Application of indigo (Indigofera tinctoria $\mathrm{L}$ ) as natural dyeing in milkfish skin tanning process. Aquat. Procedia, 7(1): 92-99.

6. Renukadevi, K.P. and Sultana, S.S. (2011) Determination of antibacterial, antioxidant and cytotoxicity effect of Indigofera tinctoria on lung cancer cell line NCI-h69. Int. J. Pharmacol., 7(3): 356-362.

7. Bahuaud, D., de Montellano, C.M.O., Chauveau, S., Prevot, F., Torres-Acosta, F., Fouraste, I. and Hoste, H. (2006) Effects of four tanniferous plant extracts on the in vitro exsheathment of third-stage larvae of parasitic nematodes. Parasitology, 132(4): 545-554.

8. Maestrini, M., Tava, A., Mancini, S., Tedesco, D. and 
Perrucci, S. (2020) In vitro anthelmintic activity of saponins from Medicago spp. against sheep gastrointestinal nematodes. Molecules, 25(2): 1-9.

9. Carvalho, V.F., Ramos, L.A., da Silva, C.A., Nebo, L., Moraes, D., da Silva, F.F.A., da Costa, N.C.A., de Rodrigues, R.O. Jr., de Souza, L.F. and Rodrigues, R.M. (2019) In vitro anthelmintic activity of Siparuna guianensis extract and essential oil against Strongyloides venezuelensis. J. Helminthol., 94(1): e50.

10. Sambodo, P., Prastowo, J., Kurniasih, K. and Indarjulianto, S. (2018) In vitro potential anthelmintic activity of Biophytum petersianum on Haemonchus contortus. Vet. World, 11(1): $1-4$.

11. Joshua, M,T., Wachuku, E.O., Boisa, N. and Nduka, N. (2020) Phytochemical screening of aqueous, ethanolic and methanolic extracts of Morus mesozygia Linn. stapf., leaves. Asian J. Biochem. Genet. Mol. Biol., 5(1): 38-46.

12. Chanwitheesuk, A., Teerawutgulrag, A. and Rakariyatham, N. (2004) Screening of antioxidant activity and antioxidant compounds of some edible plants of Thailand. Food Chem., 92(3): 491-497.

13. Wisal, Azorji, J.N., Khattak, W., Basit, M,F., Johnny, I.I., Khan, Y., Abbas, M., Izundu, M.I., Muslim, U. and Asad, F. (2020) Phytochemical assessment, in vivo hepatoprotective and nephroprotective evaluation of Aerva javanica crude methanolic extract. Asian J. Biochem. Genet. Mol. Biol., 4(2): 1-12.

14. Sambodo, P., Prastowo, J., Kurniasih, K., Mubarokah, W.W. and Indarjulianto, S. (2020) In vivo efficacy of Biophytum petersianum on Haemonchus contortus in goats. Adv. Anim. Vet. Sci., 8(3): 238-244.

15. Mubarokah, W.W., Nurcahyo, W., Prastowo, J. and Kurniasih, K. (2019) The population, protein profile and ultrastructure of Ascaridia galli in chicken treated using Areca catechu crude aqueous extract. J. Indones. Trop. Anim. Agric., 44(4): 392-399.

16. Rahman, T.U., Zeb, M.A., Liaqat, W., Sajid, M., Hussain, S. and Choudhary, M.I. (2018) Phytochemistry and pharmacology of genus Indigofera: A review. Rec. Nat. Prod., 12(1): 1-13.

17. Verma, S.M. and Suresh, K.B. (2002) Phytochemical investigation of Indigofera tinctoria Linn leaves. Anc. Sci. Life, 21(4): 235-239.

18. Misra, D.N., Gomare, K.S. and Sheelwant, S.V. (2020) GC-MS Analysis and phytochemical screening of Indigofera tinctoria (Linn.) leaf extract characterizing its medicinal use. Int. J. Ayurvedic Med., 11(2): 289-299.

19. Baihaqi, Z.A., Widiyono, I. and Nurcahyo, W. (2020) In vitro anthelmintic activity of aqueous and ethanol extracts of Paraserianthes falcataria bark waste against Haemonchus contortus obtained from a local slaughterhouse in Indonesia. Vet. World, 13(8): 1549-1554.

20. Klongsiriwet, C., Quijada, J., Williams, A.R., MuellerHarvey, I., Williamson, E.M. and Hoste, H. (2015) Synergistic inhibition of Haemonchus contortus exsheathment by flavonoid monomers and condensed tannins. Int. J. Parasitol. Drugs Drug Resist., 5(3): 127-134.

21. Ferreira, L.E., Castro, P.M.N., Chagas, A.C.S., França, S.C. and Beleboni, R.O. (2013) In vitro anthelmintic activity of aqueous leaf extract of Annona muricata L. (Annonaceae) against Haemonchus contortus from sheep. Exp. Parasitol., 134(3): 327-332.

22. Ahmed, A.H., Ejo, M., Feyera, T., Regassa, D., Mummed, B. and Huluka, S.A. (2020) In vitro anthelmintic activity of crude extracts of Artemisia herba-alba and Punica granatum against Haemonchus contortus. J. Parasitol. Res., 2020: 4950196.

23. Zaman, M.A., Qamar, W., Yousaf, S., Mehreen, U., Shahid, Z., Khan, M.K., Qamar, M.F. and Kamran, M. (2019) In vitro experiments revealed the anthelmintic potential of herbal complex against Haemonchus contortus. Pak. Vet. J., 40(2): 1-3.
24. Widiarso, B., Nurcahyo, W., Kurniasih, K. and Prastowo, J. (2017) The effect of apus bamboo (Gigantochloa apus) leaves infusion on mortality rate and morphometry of Haemonchus contortus adult worm in vitro. J. Ked. Hewan, 11(4): 156-159.

25. Zhong, R.Z., Sun, H.X., Liu, H.W. and Zhou, D.W. (2014) Effects of tannin acid on Haemonchus contortus larvae viability and immune responses of sheep white blood cells in vitro. Parasite Immunol., 36(2): 100-106.

26. Sandika, B., Raharjo. and Ducha, N. (2012) The effect of Punica granatum L infusion extract against mortality of Ascaris suum Goesze in vitro. LenteraBio, 1(2): 81-86.

27. Acevado-Ramírez, P.M.C., Calleros, C.H., Pérez, I.F., Hurtado, F.A., Mendoza-Garfías, M.B., Campo, N.C. and Barajas, R. (2019) Anthelmintic effect and tissue alterations induced in vitro by hydrolysable tannins on the adult stage of the gastrointestinal nematode Haemonchus contortus. Vet. Parasitol., 266: 1-6.

28. Martínez-Ortíz-De-Montellano, C., Arroyo-López, C., Fourquaux, I. and Torres-acosta, J.F.J. (2013) Scanning electron microscopy of Haemonchus contortus exposed to tannin-rich plants under in vivo and in vitro conditions. Exp. Parasitol., 133(3): 281-286.

29. Yoshihara, E., Minho, A.P., Tabacow, V.B.D., Cardim, S.T. and Yamamura, M.H. (2015) Ultrastructural changes in the Haemonchus contortus cuticle exposed to Acacia mearnsii extract. Semina, 36(6): 3763-3768.

30. Barone, C.D., Zajac,A.M., Manzi-Smith, L.A., Howell,A.B., Reed, J.D., Kruegerd, C.G. and Petersson, K.H. (2018) Anthelmintic efficacy of cranberry vine extracts on ovine Haemonchus contortus. Vet. Parasitol., 253: 122-129.

31. Tresia, G,E., Evvynernie, D. and Tiuria, R. (2016) Phytochemical screening and in vitro ovicidal, larvacidal, and nematicidal effects of Murraya paniculata (L.) jack extract on gastrointestinal parasites of goats. Med. Peternakan, 39(3): 173-179.

32. Ropiak, H.M., Desrues, O., Williams, A.R., Ramsay, A., Mueller-Harvey, I. and Thamsborg, S.M. (2016) Structureactivity relationship of condensed tannins and synergism with trans-cinnamaldehyde against Caenorhabditis elegans. J. Agric. Food Chem., 64(46): 1-40.

33. Jaiswal, A.K., Sudan, V., Pandey, V., Singh, A., Gaur, R.S., Kanojiya, D., Nigam, R. and Shaanker, D. (2014) Sexdependent alterations in the protein characterization patterns of Haemonchus contortus. J. Parasit. Dis., 40(3): 1006-1008.

34. Hoste, H., Jackson, F., Athanasiadou, S., Thamsborg, S.M. and Hoskin, S.O. (2006) The effects of tannin-rich plants on parasitic nematodes in ruminants. Trends Parasitol., 22(6): 253-261.

35. Simon, M.K., Ajanusi, O.J., Abubakar, M.S., Idris, A.L. and Suleiman, M.M. (2012) The anthelmintic effect of aqueous methanol extract of Combretum molle (R. Br. X. G. Don) (Combretaceae) in lambs experimentally infected with Haemonchus contortus. Vet. Parasitol., 187(1-2): 280-284.

36. González-Cortazar, M., Zamilpa, A., López-Arellano, M.E., Aguilar-Marcelino, L., Reyes-Guerrero, D.E., OlazaránJenkins, S., Ramírez-Vargas, G., Olmedo-Juárez, A. and Mendoza-De-Gives, P. (2017) Lysiloma acapulcensis leaves contain anthelmintic metabolites that reduce the gastrointestinal nematode egg population in sheep faeces. Comp. Clin. Pathol., 27(1): 189-197.

37. Eguale, T., Tilahun, G., Debella, A., Feleke, A. and Makonnen, E. (2007) In vitro and in vivo anthelmintic activity of crude extract of Coriandrum sativum against Haemonchus contortus. J. Ethnopharmacol., 110(3): 428-433.

38. Meenakshisundaram, A., Harikrishnan, T.J. and Anna, T. (2016) Anthelmintic activity of Indigofera tinctoria against gastrointestinal nematodes of sheep. Vet. World, 9(1): 101-106.

\section{$* * * * * * * *$}

